\title{
KOMBINASI BILAKUPU (BIJI LABU KUNING DAN KUNYIT PUTIH) DALAM MENURUNKAN HIPERKOLESTEROLEMIA
}

\author{
Evita Puspaningdyah ${ }^{1}$, Dheasy Herawati ${ }^{2)}$ \\ ${ }^{1)}$ Program Studi D3 Ahli Teknologi Laboratorium Medik, Fakultas Ilmu Kesehatan, \\ ${ }^{2}$ Penulis Korespondensi, Program Studi D3 Ahli Teknologi Laboratorium Medik, Fakultas Ilmu \\ Kesehatan, Universitas Maarif Hasyim Latif \\ Email :dheasy_herawati@dosen.umaha.ac.id
}

\begin{abstract}
ABSTRAK
Kolesterol merupakan senyawa lemak yang lunak, seperti lilin yang diproduksi oleh hati dan sisanya diperoleh dari makanan. Hiperkolesterolemia adalah kadar kolesterol yang melebihi batas normal dalam darah atau $>200 \mathrm{mg} / \mathrm{dl}$ (nilai normal $40-130 \mathrm{mg} / \mathrm{dl}$ ). Biji labu kuning (Cucurbita moschata) dan kunyit putih (Curcuma mangga Val.) merupakan tanaman yang mudah didapatkan di Indonesia.Tujuan penelitian ini ialah untuk mengetahui pengaruh kombinasi serbuk biji labu kuning (Cucurbita moschata) dan rebusan kunyit putih (Curcuma mangga Val.) dalam menurunkan kadar kolesterol darah pada mencit. Pengumpulan data pada penelitian ini menggunakan studi eksperimental yaitu denganmenggunakan 30 ekor mencit yang dibagi menjadi 3 kelompokyaitu kontrol normal (kandang 1) dengan pemberian pakan ayam cp 511, kontrol positif (kandang 2) dengan pemberian jeroan ayamdan kontrol terapi (kandang 3) dengan pemberian BILAKUPU.Hasil penelitian menunjukkanadanya perbedaan antara kelompok kontrol positif dengan kelompok kontrol terapi yang ditunjukkan dengan uji statistik yaitu uji Paired T-Test menunjukkan hasil signifikansi $0,000(\mathrm{p}<$ $0,05)$ yang menunjukkan bahwa kombinasi BILAKUPU dapat menurunkan kadar kolesterol darah secara bermakna.
\end{abstract}

Kata kunci : Hiperkolesterolemia, Biji labu kuning, Kunyit putih, Mencit.

\section{PENDAHULUAN}

Penggunaan tumbuhan obat di Indonesia sebenarnya sudah dimulai dari zaman nenek moyang bangsa Indonesia.Akan tetapi, penggunaannya di tengah masyarakat baru dimulai pada zaman penjajahan Belanda(Hariana, 2013).

Tumbuhan obat yang digunakan sebagai obat alternatif diantaranya adalah kunyit putih (Curcurma mangga Val.)Di dalam rimpang kunyit putih terdapat beberapa kandungan yang berkhasiat yaitu kurkumin, flavonoid, polifenol, dan minyak atsiri (Pujimulyani dkk, 2010).

Salah satu bahan yang dapat digunakan lainnya adalah biji labu kuning (Cucurbita moschata).Pada masyarakat masih jarang digunakan.Kebanyakan masyarakat tidak memanfaatkan bijinya dan hanya memanfaatkan buahnya untuk produksi makanan. Didalam biji labu kuning memiliki kandungan fitosterol, vitamin C, E, beta karoten, dan mineral (magnesium, selenium, dan zink) (Mayasari dan Rahayuni, 2014).

Pada saat ini banyak masalah kesehatan yang telah bergeser dari penyakit infeksi ke penyakit degeneratif. Penyebabnya diduga akibat perubahan gaya hidup, pola makan, faktor lingkungan, kurangnya aktivitas fisik dan faktor stres. Gaya hidup yang kurang beraktivitas, terlalu banyak mengonsumsi makanan mengandung lemak dan kolesterol serta kurangnya asupan serat dapat memicu penyakit degeneratif. Kolesterol merupakan unsur penting dalam tubuh yang diperlukan untuk mengatur proses kimiawi di dalam 
tubuh, tetapi kolesterol dalam jumlah tinggi bisa menyebabkan aterosklerosis yang akhirnya berdampak pada penyakit jantung koroner(Rahayu, 2005).

Hiperkolesterolemia merupakan salah satu masalah kesehatan yang menjadi perhatian dunia karena prevalensi kejadiannya yang tinggi. Menurut WHO (2017) Pada tahun 2008, prevalensi global peningkatan kolesterol total pada orang dewasa adalah $39 \%$ (37\% untuk laki-laki dan $40 \%$ untuk wanita). Peningkatan kolesterol total merupakan penyebab utama penyakit baik di negara maju maupun negara berkembang, salah satunya di Amerika, prevalensi penyakit hiperkolesterolemia mencapai $16,2 \%$ pada usia dewasa, sedangkan di Bangladesh dan Nepal ditemukan 16\% dan 13\% kejadian hiperkolesterolemia.

Menurut penelitian terdahulu, mengonsumsi biji labu kuning selama 8 minggu pada tikus yang mengalami aterosklerosis (terjadinya penyempitan pada pembuluh darah) dapat menurunkan kadar Kolesterol sebanyak 79\% secara signifikan dari 3,33 mmol/L (Mayasari, 2014), namun pada penelitian ini, pemberian biji labu kuning dilakukan dengan cara mencampurkan biji labu kuning ke dalam rebusan kunyit putih.

Kunir putih jenis mangga (Curcuma mangga $\mathrm{Val}$.) mempunyai khasiat yang baik untuk kesehatan yang dapat membantu menormalkan tensi, kolesterol, gula darah, asam urat, trigliserida, serta kegemukan.Selain itu temu mangga dapat menurunkan keganasan sel kanker(Pujimulyani, 2016).

\section{METODOLOGI PENELITIAN}

\section{Tempat dan Waktu Penelitian}

Penelitian dilakukan di Laboratorium Pusat Veteriner Farma (PUSVETMA)

\section{Alat Penelitian}

Alat penelitian yang digunakan dalam penelitian ini berupa :strip kolesterol, alat test easy touch, sonde, kandang mencit, timbangan, gunting, kapas, alkohol 70\%, handscoond, masker, jas laboratorium

\section{Bahan Penelitian}

Bahan penelitian yang digunakan dalam penelitian ini berupa : mencit betina usia 2-3 bulan dengan berat rata-rata 25-30 gram, pakan ayam CP 511, jeroan ayam yang sudah dihaluskan, bahan terapi berupa kombinasi serbuk biji labu kuning dan rebusan kunyit putih.

\section{Prosedur Penelitian}

\section{Persiapan Sampel}

1. Pembuatan Sediaan Pakan Tinggi Kolesterol

Jeroan ayam yang sudah digoreng serta dihaluskan dengan diblender diencerkan dengan air, kemudian dilakukan penyaringan dan disondekan dengan takaran 0,8 cc selama tujuh hari pertama, diberikan setiap pagi $1 \mathrm{x} 1$ hari.

2. Pembuatan Sediaan Bahan Uji

a. Serbuk Biji Labu Kuning (Cucurbita moschata)

Biji labu kuning dijemur di bawah sinar matahari selama 3-7 hari, kemudian diblender dan disaring menjadi serbuk hingga menghasilkan 10 gram serbuk biji labu kuning.

b. Rebusan Kunyit Putih (Curcuma mangga Val.)

Disiapkan 10 gram rimpang kunyit putih cuci hingga bersih, kemudian dipotong tipis - tipis dan rebus dengan $100 \mathrm{cc}$ air, tunggu sampai tinggal setengahnya (mendidih). Saring dan dinginkan.

c. Pencampuran Serbuk Biji Labu Kuning Dan Rebusan Kunyit Putih

Pemberian bahan terapi dilakukan dengan perbandingan 10\%: 10 gram yaitu dengan rebusan kunyit putih yang kemudian ditambahkan 10 gram serbuk biji labu kuningdalam $100 \mathrm{ml}$ rebusan kunyit putihdan diaduk secara merata. 
Kemudian disondekan pada mencit yang sudah dalam keadaan Hiperkolesterol.

\section{Prosedur Pemeriksaan}

Menyiapkan mencit sebanyak 30 ekor mencit yang dibagi menjadi 3 kandang, masing-masing berisi 10 ekor mencit betina. Pada hari pertama kandang ke-1 kontrol normal di periksa kadar kolesterol, kandang ke-2 (kontrol positif) dan kandang ke-3 (kontrol terapi) diberi halusan jeroan ayam sebanyak 0,8 cc pada lambung mencit menggunakan alat sonde selama 7 hari berturut-turut.

Hari ke-7 kandang kontrol positif dan kontrol terapi diperiksa kadar kolesterol. Kemudian hari ke-8 kandang ke-2 kontrol positif diberi pakan biasa, sedangkan pada kandang ke-3 kontrol terapi diberikan kombinasi serbuk biji labu kuning dan rebusan kunyit putih sebanyak $0,8 \mathrm{cc}$ (hari ke- 8 sampai hari ke-14). Dua jam setelah pemberian terapi diperiksa kadar kolesterolnya dengan cara diberi kapas alcohol 70\%, kemudian ekor mencit digunting kurang lebih $0,5 \mathrm{~cm}$ dari ujung ekor mencit setelah keluar darahnya diteteskan pada ujung stick kolesterol sampai keperluan darah terpenuhi. Tunggu hingga hasilnya keluar pada monitor alat

\section{HASIL DAN PEMBAHASAN}

Penelitianini bertujuan untuk mengetahui kombinasi BILAKUPU (biji labu kuning dan kunyit putih) terhadap penurunan hasil kadar kolesterol yang disajikan dengan tabel di bawah ini:

Tabel 1. Hasil pemeriksaan kadar kolesterol pada mencit

\begin{tabular}{|c|c|c|c|c|}
\hline No. & $\begin{array}{c}\mathrm{K} . \\
\text { Normal } \\
(\mathrm{mg} / \mathrm{dL})\end{array}$ & $\begin{array}{c}\mathrm{K} . \\
\text { Positif } \\
\text { sth } 7 \\
\text { hari } \\
(\mathrm{mg} / \mathrm{dL})\end{array}$ & $\begin{array}{c}\mathrm{K} . \\
\text { positif } \\
\text { Sth14 } \\
\text { Hari } \\
\text { (mg/d } \\
\mathrm{L})\end{array}$ & $\begin{array}{c}\mathrm{K} . \\
\text { Terapi } \\
\text { sth } 14 \\
\text { hari } \\
(\mathrm{mg} / \mathrm{dL})\end{array}$ \\
\hline 1. & 111 & 152 & 147 & 100 \\
\hline
\end{tabular}

\begin{tabular}{|c|c|c|c|c|}
\hline 2. & 108 & 170 & 164 & 118 \\
\hline 3. & 112 & 169 & 162 & 124 \\
\hline 4. & 105 & 165 & 156 & 106 \\
\hline 5. & 102 & 176 & 168 & 125 \\
\hline 6. & 107 & 157 & 152 & 119 \\
\hline 7. & 115 & 165 & 157 & 121 \\
\hline 8. & 109 & 180 & 175 & 113 \\
\hline 9. & 106 & 189 & 184 & 115 \\
\hline 10 & 108 & 175 & 169 & 117 \\
\hline$\Sigma$ & 1083 & 1698 & 1634 & 1158 \\
\hline$\Sigma \mathrm{x}$ & 108,3 & 169,8 & 163,4 & 115,8 \\
\hline
\end{tabular}

Dari data tabel tersebut dibuatlah grafik sebagai berikut :



Gambar 1.Grafik hasil rata-rata kadar kolesterol $\mathrm{mg} / \mathrm{dl}$.

kontrol positif $=$ kontrol terapi sebelum diberi terapididapatkan hasil dengan rata-rata 169,8 $\mathrm{mg} / \mathrm{dl}$ dan kontrol normal (tidak mengalami peningkatan kolesterol = tidak sakit). Beda dengan kontrol positif dan Kontrol terapi (mengalami peningkatan kadar kolesterol). Hal ini dikarenakan pada pemberian pakan tinggi kolesterol berupa ampela dan hati ayam (jeroan ayam) memiliki kandungan berupa lemak jenuh.Jadi penurunan yang terjadi pada kontrol positif setelah 7 hari (hari ke-14) pemberian pakan biasadidapatkan hasil dengan rata-rata $163,4 \mathrm{mg} / \mathrm{dl}$, di manamengalami sedikit penurunan, dikarenakan penghentian dari pakan tinggi kolesterol yaitu jeroan ayam.Setelah pemberian terapi pada Kontrol terapi didapatkan hasil dengan rata-rata 115,8 $\mathrm{mg} / \mathrm{dl}$. Hal ini dikarenakan pemberian 
kombinasi BILAKUPU(biji labu kuning dan kunyit putih) yang dapat menyebabkan penurunan kadar kolesterol.

Untuk mengetahui apakah data tersebut terdapat perbedaan kadar kolesterol antar kelompok perlakuan, data dari hasil penelitian ini dilanjutkan dengan uji statistik yaitu uji normalitas. Dari uji normalitas yang telah dilakukan menunjukkan hasil sig: 0,864. Berdasarkan data Shapiro-wilk pada penentuan $p>0,05$ didapatkan data berdistribusi normal.

Dengan data yang normal, maka dilanjutkan ke uji parametrik yaitu uji Paired T-Test yang menunjukkan hasil sig. (2-tailed) 0,000 dan berdasarkan data tersebut pada penentuan $\mathrm{p}<0,05$ dinyatakan terdapat perbedaan antara sebelum dan sesudah pemberian terapi serbuk biji labu kuning dan rebusan kunyit putih secara bermakna.

Hal ini dikarenakan didalam biji labu kuning memiliki kandungan senyawa kimia Fitosterol sebesar $10,85 \mathrm{mg} / 100 \mathrm{~g}$. Fitosterol memiliki rantaiterbuka yang bisa mengikat kolesterol jahat dan membawanya keluar dari pembuluh darah.Fitosterol memiliki kemampuan untuk berkompetisi dengan kolesterol dalam penyerapan di dalam usus. Fitosterol akan menghambat penyerapan kolesterol dengan cara mengikat misel yang merupakan alat transportasi penyerapan kolesterol di dalam usus. Kompetisi ini mengakibatkan berkurangnya jumlah kolesterol yang dapat diserap oleh tubuh (Pardede, 2013). Fitosterol akan lebih mudah dihidrolisis dibandingkan dengan kolesterol, sehingga dapat mengakibatkan terjadi penurunan penyerapan plasma total kolesterol karenadiekskresikan melalui feses (Andari, 2014).

Sedangkan kandungan pada kunyit putih yang mengandung polifenol melalui efek antioksidannya (Hartoyo, 2003). Senyawa polifenol yang terkandung di dalam kunyit putih sebesar $14,80 \mathrm{mg} / 100 \mathrm{~g}$. Kunyit putih juga mengandung kurkumin sebesar 84,50 $\mathrm{mg} / 100 \mathrm{~g}$ sebagai anti inflamasi dan antiseptik.
Polifenol yang terkenal sebagai katekin.Katekin adalah senyawa antioksidan kuat bahkan melebihi dari vitamin E, vitamin C, dan betakaroten.Polifenol mampu melindungi sel-sel dalam tubuh terhadap kerusakan yang disebabkan oleh radikal bebas.Senyawa polifenol dapat memberantas radikal bebas seperti peroksida, hidroperoksida atau peroksil lipid, sehingga menghambat mekanisme oksidasi (Mokgope, 2006). Polifenol merupakan antioksidan sekunder yang mampu menangkal radikal bebas di dalam tubuh. Mekanisme polifenol sebagai antioksidan sekunder yaitu dengan cara memotong reaksi oksidasi berantai dari radikal bebas, sehingga radikal bebas tidak akan bereaksi dengan komponen seluler (Sayuti dan Yenrina, 2015).

Hal ini berarti $\mathrm{H} 0$ ditolak dan $\mathrm{H} 1$ diterima, yang bisa diartikan adanya perbedaan antara perlakuan tanpa terapi (kontrol positif) dengan perlakuan pemberian terapi serbuk biji labu kuning dan rebusan kunyit putih terjadi penurunan kadar kolesterol darah pada mencit.

\section{KESIMPULAN}

Dari penelitian yang telah dilakukan dapat disimpulkan bahwa kombinasi serbuk biji labu kuning (Cucurbita moschata)dan rebusan kunyit putih (Curcuma manga Val.) dapat menurunkan kadar kolesterol darah mencit.

\section{SARAN}

Berdasarkan dari hasil simpulan tersebut, maka peneliti mempunyai saran antara lain:

1. Penanganan dan pengolahan biji labu kuning harus higienis untuk mengurangi resiko terjadinya pertumbuhan jamur.

2. Bagi peneliti selanjutnya disarankan untuk membandingkan antara kandungan serbuk biji labu kuning dengan rebusan kunyit putih yang lebih cepat dalam menurunkan kadar kolesterol. 


\section{DAFTAR PUSTAKA}

Andari F. 2014. Pengaruh Pemberian Serbuk Biji Labu Kuning(Cucurbita moschata) Terhadap Penurunan Kolesterol Total Pada Tikus Wistar Hiperkolesterolemia. Jurnal Fakultas Kedokteran Universitas Dipenogoro. Semarang.

Hariana, H.A. 2013.262 Tumbuhan Obat dan Khasiatnya.Penebar Swadaya.

Hartoyo, A. 2003.Teh dan Khasiatnya Bagi Kesehatan. Penerbit Kanisius. Yogyakarta.

Mayasari, D.R dan Rahayuni, A. 2014.Pengaruh Pemberian Serbuk Biji Labu Kuning (Cucurbita moschata) Terhadap Penurunan Kolesterol LDL Pada Tikus Wistar Hiperkolesterolemia. Jurnal Fakultas Kedokteran Universitas Dipenogoro. Vol. 3, No. 4. Semarang.

Mokgope, L.B. 2006.Cowpea Seeed Coats and Their Extracts: Phenolic Composition and Use as Antioxidants in Sunflower Oil. Afrika: University og Pretoria. Dalam (Umarudin, dkk. 2012. Efektivitas Ekstrak Tanin Seledri Terhadap Profil Lipid Tikus Putih Hiperkolesterolemi. Jurusan Biologi FMIPA, Universitas Negeri Semarang.

Pardede, Erika. 2013. Tinjauan Komposisi Kimia Buah dan Sayur: Peranan Sebagai Nutrisi dan Kaitannya dengan Teknologi Pengawetan dan Pengolahan. Jurnal Program Studi Ilmu dan Teknologi Pangan.Universitas HKBP Nommensen. Medan.

Pujimulyani., dkk. 2010. Aktivitas Antioksidan Dan Kadar Senyawa Fenolik Pada Kunir Putih (Curcuma mangga val.) Segar Dan Setelah BLANCING. Jurnal
Fakultas Agroindustri, Universitas Mercu Buana. Yogyakarta.

Rahayu, T. 2005. Kadar Kolesterol Darah Tikus Putih (Rattus norvegicus) Setelah Pemberian Kombucha Cairan Per-Oral. http://www.eprints.ums.ac.id/408/2005/t homs. Html. Diakses 18 Desember 2018 .

Sayuti, K. dan Yenrina, R. 2015.Antioksidan Alami dan Sintetik.Cetakan I. Asosiasi Penerbit Perguruan Tinggi Indonesia (APTT). Padang. 